\title{
雨水利用に対する助成制度等のデータベースについて
}

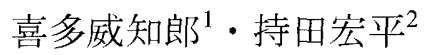

\section{Database on Subsidies for Rainwater Use}

\author{
Ichiro Kita ${ }^{1}$ and Kohei Mochida ${ }^{2}$
}

\section{1 はじめに}

水資源の有効利用や都市型洪水等の環境問題を緩和寸 るために, 雨水利用が注目され, 雨水利用施設が普及 しつつある。 その普及の促進を目的として, 助成制度 を制定し，実施する地方自治体が増加している。雨水 利用がさらに普及寸るためには，この助成制度が広く 住民に周知され，利用される必要がある.

近年，インターネットの普及は顕著であり，日常の 情報収集伝達手段として必須のものとなっている。イ ンターネットには, 膨大な量の情報が蓄積されている ものの，迅速かつ的確に必要な情報にアクセス寸るの は，たやすくない。

本報では，雨水利用に関する情報の集約に特化し， 情報を提供するとともに，提供も受けることができる インタラクティブなデータベースを構築した。

\section{2 雨水利用に対する助成制度の必要性}

都市部で渴水による安定した水供給能力の低下が懸念 される一方で，集中豪雨時には，都市型洪水が生じて いる。.また，地下水位心低下や湧水の枯渴が生じてい ることも報告されている。都市域では地表面がコンク リート・アスファルト構造物等で覆われため, 不浸透 域面積が増大し，雨水の地中一の浸透が遮られること がこれらの現象を引き起こす主要な原因とされている.

都市用水は, 多くの場合, 都市域から遠く離れた山 間部等への降水にその供給源を依存しており，山間部 等への集水域への降水は，水資源の源として利用され ているにも関わらず，同じ降水が都市域一降った場合 は，速やかに排除されるべきものであると考えられ， 効率的に下水道等に集水し，速やかに排水することに 関心が払われてきている。生活環境の快適性を保持寸 るという観点からみれば, その必要性は否定できない。 しかし，水資源の有効利用や環境保全の観点加らみ机 ば，都市域一の降水を活用寸ることは重要である。こ のように，地市域に抢ける雨水はトレードオフの関係 にあり，適切な妥結点を見いだす必要がある。

このトレードオフの解決点を与える一つの方策とし て, 雨水利用が注目されている. 近年, 雨水利用施設 が導入される事例は増加しているが，公共施設等に設

1 島根大学生物資源科学部教授, Professor, Faculty of Life and Environment Science, Shimane University, Matsue, Shimane, 690-8504 Japan

2 株式会社セラク, SERAKU Co., Ltd., 7-5-25, Nishi-shinjuku, Shinjuku, Tokyo, 160-0023 Japan
置される比較的大規模なものが主なものになっている. これらがもたらす効果はその設置された施設の容量に 大きく依存寸る. 大規模な建造物一の雨水貯留施設の 設置は, 新たに築造する場合, 当初からその設置を計 画し，それに応じた設計をすれば，たやすく設置する ことができる。しかし，既存の大規模な建造物一雨水 利用施設を設置するのは，設置する場所の確保や工法 等を考えれば，容易ではない。

そこで，雨水利用施設がもたらす効果を顕著なもの と寸るためには，個人住宅や民間事業所等一小規模な 雨水利用施設が導入される必要がある。たとえ，小規 模なものであっても, 多数の雨水貯留施設が設置され れば，大規模なものに匹敵するだけの効果を得ること ができ，小規模なものであれば，設置自体も容易であ る.しかし，雨水利用施設の導入にあたっては，必要 な費用が 1 つの障壁になるであろう。設置者側からみ れば，雨水貯留施設の導入が環境問題の緩和や水資源 の節約等に意義があることを十分理解したとしても， 必要な費用に対してそれに見合うだけの便益を得るこ とが保証されない限り，その設置を躊躇することが容 易に推測できる。特に，個人住宅一小規模雨水利用施 設を導入する場合，よほど，環境問題に対して高い意 識を持っていなければ, 設置に踏み切れないであろう。 そのため, 雨水利用施設の普及を一層促進するために, 雨水利用施設に対寸る助成制度を制定し，害施してい る地方自治体が増加している。

\section{3 雨水利用データベース}

\section{1 開発の目的}

我が国のインターネット利用人口は、この数年間, 急 激に増加を続けている。平成15年末のインターネット 利用人口は，6歳以上の人口を対象とした場合，パソコ ン, 携帯電話, PHS等のうち, 1 つ以上の機器加ら利用 しているのは，7,730万人と推計され，人口普及率は $60.6 \% ， 300$ 人以上の企業，および世帯普及率はそれぞ れ，98.2\%，82.6\%， $88.1 \%$ であり，日常的に利用寸る 環境が整備されてきたといえよう。平成16年2月には, 425,000台のサーバーに, ページ数 29,173 万ページ, 総 ファイル数8,590万ファイル, 総データ量 $13,609 \mathrm{~GB}$ の情 報量が蓄積されている。インターネットの利用目的の 約6割が情報検索, 収集である。このように，インター ネットは我々の日常生活に抢いては, 重要な情報伝達 
手段と位置づけることができる.

官公斻・企業・個人・団体等がサイトを開設し，多 くの情報の発信源から様々な情報が発信されている. 情報を必要と寸る場合，このような膨大な情報源から， 迅速かつ的確に必要な情報にアクセス寸ることを支援 することを目的とした検索エンジンも数多く提供され てきている，これらの検索エンジンは，常時，改良が 行われ，必要とする情報が揭示されているWebページ にたやすく，アクセスできる工夫がなされている.

検索エンジンでは，必要とする情報に関連する複数 のキーワードを入力・送信した後, 表示されるWebぺ 一ジを閲覧して，目的とする情報が含まれているか， 確認寸る必要がある。もし，必要な情報を含むWebぺ ージにアクセスできなければ, キーワードを変更して, 同様の操作を繰り返す必要がある等, 試行錯誤的な過 程が必要となる。そこで，このような問題を解決する ために，ポータルサイトが開設されてきた。ポータル サイトとは，インターネットにおいて情報への入り口 となるようなサイトのことを意味している。この種の ポータルサイトは各検索エンジンで検索を行った際に, 比較的上位に表示されるため，広く利用されている。

本報では，雨水利用に特化したポータルサイトとし て, 雨水利用に関する助成制度と雨水利用に関連する 商品に関する情報に限定して集約し，利用者に情報を 提供するだけでなく，利用者側からも情報の提供を受 け，データベース内容を一層充実することができるよ うなインタラクティブなデータベースシステムの構築 を目的とした。

\section{2 情報の検索}

今回構築したシステムでは，キーワード検索，カテゴ リ検索, 条件検索の3つの方法で検索を行えるようにし た。図1に示寸トップページおよび条件検索ページか ら行うことができるキーワード検索は，全データの中

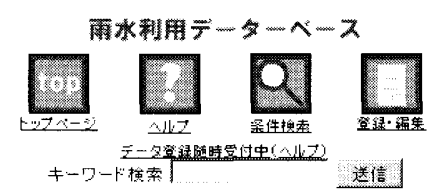

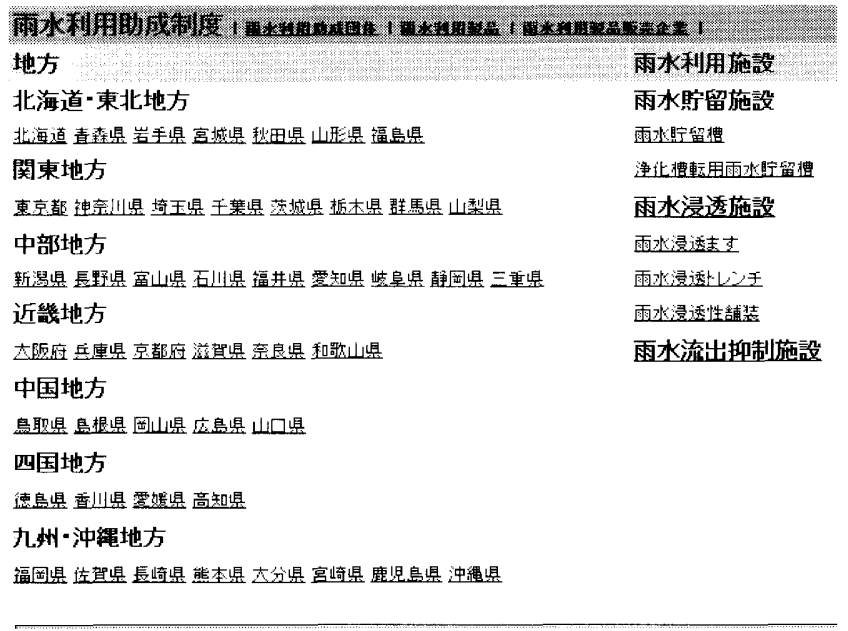

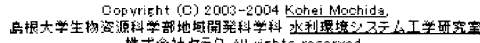

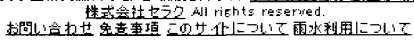

図 1: 雨水利用データベーストップページ
から指定されたキーワードを含むデータを取り出す方 法である。この方法は即座に情報を得ることが可能で あるが，キーワードによっては，目的とは異なる情報 も多く出力されてしまう。

カテゴリ検索は目的の情報のカテゴリを選択してい くことによって，最終的にその情報にアクセスする方 法である。この方法は, 自分でカテゴリを指定してい くので高い確率で必要な情報を得ることができるが, 比較的多くの手順を踏む必要がある。 また，その情報 について熟知していなければ，検索を行うことができ ない，今回のシステムでは, トップページから各カテ ゴリへのアクセスが可能である.

条件検索ぺージから行うことができる条件検索は， 検索の条件を細かく指定することで，目的のデータに アクセス寸る方法である。この方法では，その情報に ついての知識が必要になるが，高い精度で目的の情報 にたどり着くことができる.

本システムでは，これらの方法を組み合わせること によって, 誰もが容易に目的の情報にアクセスできる ように配慮している。 これらの検索によって出力され た検索結果からは，それぞれのデータの詳細を閲覽す ることができる.

\section{3 利用者からの情報の提供}

データベースではデータ量およびデータの信頼性が重 要となる。そそのため，より多くの信頼できるデー夕を 登録できる様に配慮したシステムが必要となる。そこ で，今回は，インターネットにアクセスできる不特定 多数がフォームを使ってデータを自由に登録できるよ うにした。 しかし, 不特定多数の情報提供者から送ら れてくる情報は, 提供者には何の責任も負う必要がな いため，必ずしも正確であるとは限らない，そこで， 不特定多数から送られたデー夕は一時的に外部から遮 断されたキューというデータベースに保存する。管理 者がそのデータの真偽を確認し，データベースに適し たデータだと判断できれば，外部から閲覧できるデー タベースへ反映するようにした。これにより,データ の信頼性を保ちつつ，多くのデータを収集することが できるものと考えられる。

\section{4 おわりに}

本報では, 雨水利用をさらに普及させるために, イン ターネット上から雨水利用に関する情報を的確に提供 する一方で，新たに情報の提供を受けて，データべー スに登録することができるインタラクティブなデータ ベースを構築した。このデータベースが効果的に利用 されるためには，その存在を広く知らしめる必要があ る. 現在, 最も膨大な情報量を蓄積するGoogle, 最も 知名度が高いYahoo!Japanの各検索エンジンで，「雨水」 または「雨水利用」のキーワードを入力すれば，上位に 表示されるので，特に，問題はないように思える.

現在の問題点としては，雨水利用製品に関する情報 量は増加しているが, 雨水利用に対する助成制度に関 する情報の提供が少ない点である。また，データベー スは常に正確な情報を提供する必要があるため，蓄積 したデータの元のデータが更新された場合，それを反 映する必要があるが, 煩雑な作業となるため, 効率的 な方法を模索する必要がある。 